\title{
Stability Indicating Method for Simultaneous RP HPLC Determination of Camylofin Dihydrochloride and Nimesulide in Pharmaceutical Preparations
}

\author{
Rajeev Kumar R. Singh, ${ }^{1,2}$ Manapragada V. Rathnam, ${ }^{1}$ Sangeeta J. Singh, ${ }^{2}$ \\ and Raju V. K. Vegesna ${ }^{2}$ \\ ${ }^{1}$ Department of Chemistry, B.N. Bandodkar College of Science, Thane-400 601, India \\ ${ }^{2}$ Analytical Development Department, Versapharm Incorporated, 1035 Louis Drive, Warminster, PA 18974, USA \\ Correspondence should be addressed to Rajeev Kumar R. Singh, kumarrajeevs@gmail.com
}

Received 16 September 2011; Accepted 16 October 2011

Academic Editors: P. Campíns-Falcó, A. Niazi, and A. Przyjazny

Copyright ( 2012 Rajeev Kumar R. Singh et al. This is an open access article distributed under the Creative Commons Attribution License, which permits unrestricted use, distribution, and reproduction in any medium, provided the original work is properly cited.

A simple, fast, and precise reversed phase high-performance liquid chromatographic method has been developed for the simultaneous determination of camylofin dihydrochloride and nimesulide using caffeine as an internal standard. The stability indicating capability of the method was proved by subjecting the drugs to stress conditions as per ICH-recommended test conditions. Separation was achieved using Varian Chromspher $5 \mathrm{C}_{18}$ column $(250 \mathrm{~mm} \times 4.6 \mathrm{~mm}, 5 \mu \mathrm{m})$ as stationary phase with a mobile phase comprising of buffer solution pH $5.0:$ methanol $(600: 400, \mathrm{v} / \mathrm{v})$ at a flow rate of $1.0 \mathrm{~mL} \mathrm{~min}^{-1}$, column temperature of $30^{\circ} \mathrm{C}$ and UV detection at $220 \mathrm{~nm}$. The retention time of caffeine, camylofin dihydrochloride, and nimesulide was about $5.0 \mathrm{~min}$, $6.1 \mathrm{~min}$, and $12.7 \mathrm{~min}$, respectively. The proposed method was validated for linearity, accuracy, precision, sensitivity, robustness and solution stability. Linearity, accuracy, and precision were found to be acceptable over the ranges of $250-750 \mu \mathrm{g} \mathrm{mL}^{-1}$ for Nimesulide and $125-375 \mu \mathrm{g} \mathrm{mL}^{-1}$ for camylofin dihydrochloride. The test solution was found to be stable for $72 \mathrm{~h}$. It can be conveniently adopted for routine quality control analysis.

\section{Introduction}

Camylofin dihydrochloride is 3-methylbutyl 2-(2-diethylaminoethylamino)-2-phenyl-acetate hydrochloride is a drug used as an antispasmodic [1].

Nimesulide is N-(4-Nitro-2-phenoxyphenyl) methanesulfonamide. Nimesulide is a relatively COX-2 selective, nonsteroidal anti-inflammatory drug (NSAID) with analgesic and antipyretic properties. Its approved indications are the treatment of acute pain, the symptomatic treatment of osteoarthritis, and primary dysmenorrhoea in adolescents and adults above 12 years old [2]. The structure of the drug is shown in Figure 1. One such combination contains $50 \mathrm{mg}$ of Camylofin dihydrochloride and $100 \mathrm{mg}$ of nimesulide.
The literature survey indicated few methods exits, for the determination of Camylofin dihydrochloride and nimesulide individually or in combination with other drug preparations by HPLC. HPLC method for the estimation of nimesulide in a formulation was reported in various pharmaceutical preparations [3-12]. An HPTLC method was reported for estimation of nimesulide in a pharmaceutical preparation [13]. An HPTLC method was reported for the estimation of Camylofin dihydrochloride in pharmaceutical preparation [14]. HPLC methods were also reported for the estimation of Camylofin dihydrochloride in pharmaceutical preparation [15-19]. The literature revealed no method was available for simultaneous determination of this drug in such pharmaceutical preparation by HPLC. Therefore, an HPLC method was 
<smiles>CCN(CC)CCNC(C(=O)OCCC(C)C)c1ccccc1</smiles>

(a)<smiles>CS(=O)(=O)Nc1ccc([N+](=O)[O-])cc1Oc1ccccc1</smiles>

(b)

FIgURE 1: Structures of Camylofin dihydrochloride $\mathrm{C}_{19} \mathrm{H}_{32} \mathrm{~N}_{2} \mathrm{O}_{2}$, $2 \mathrm{HCl}$ (a) and Nimesulide $\mathrm{C}_{13} \mathrm{H}_{12} \mathrm{~N}_{2} \mathrm{O}_{5} \mathrm{~S}$ (b).

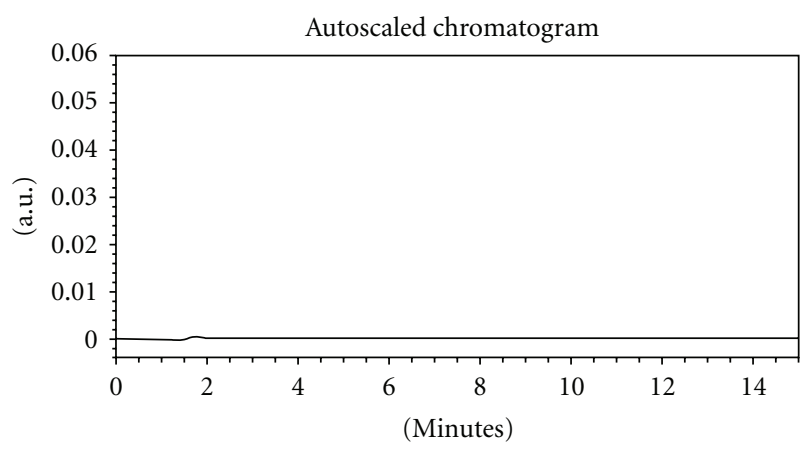

FIgURe 2: A typical chromatogram of diluent (blank).

developed for determination of Camylofin dihydrochloride and nimesulide from their dosage form.

\section{Experimental}

2.1. Chemicals and Reagents. Anafortan $\mathrm{N}$ tablets manufactured by Khandelwal lab, India were procured from the pharmacy. Anafortan $\mathrm{N}$ tablets is a combination of camylofin dihydrochloride $50 \mathrm{mg}$ and nimesulide $100 \mathrm{mg}$. camylofin dihydrochloride (Purity 99.8\%) and nimesulide (Purity 99.7) were procured from Sigma Aldrich (USA). Potassium dihydrogen orthophosphate and methanol were from EMD Chemicals (USA). Double distilled water was employed

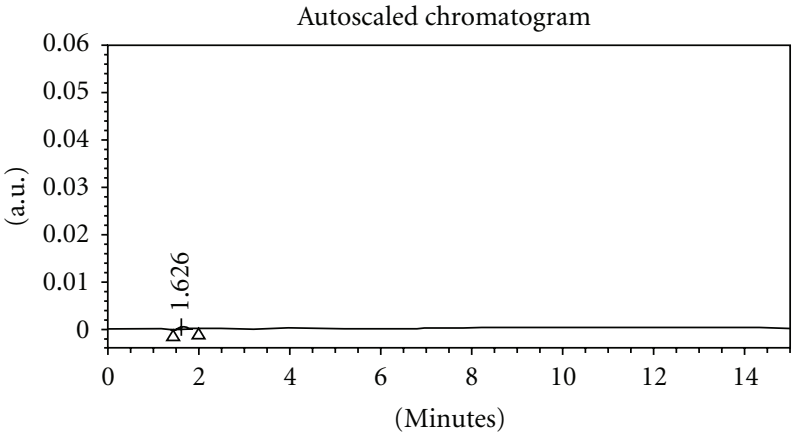

Figure 3: A typical chromatogram of Placebo preparation.

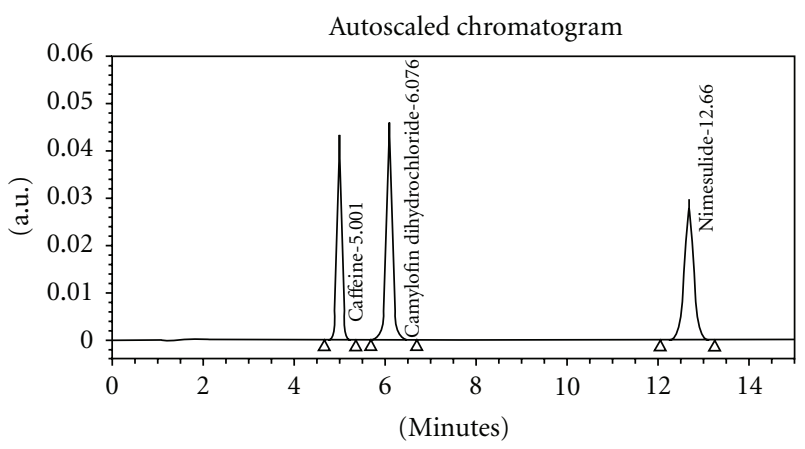

FIGURE 4: A typical chromatogram of standard preparation: caffeine (5.001 $\mathrm{min})$, camylofin dihydrochloride $(6.076 \mathrm{~min})$, and nimesulide (12.660 $\mathrm{min})$.

throughout the work. All dilutions were performed in standard volumetric flasks.

2.2. LC Instrument and Condition. The high-pressure liquid chromatography (HPLC) system was used of waters 2695 series equipped gradient pump, autosampler, thermo stated column compartment, a photo-diode array detector (2996). Chromatograms and data were recorded by means of Empower software. Varian Chromspher $5 \mathrm{C}_{18}$ column $(250 \mathrm{~mm} \times 4.6 \mathrm{~mm}, 5 \mu \mathrm{m})$ was used as a stationary phase. The mobile phase comprising of buffer solution $\mathrm{pH}$ 5.0 : methanol $\left(600: 400\right.$, v/v) was used. $0.01 \mathrm{M} \mathrm{KH}_{2} \mathrm{PO}_{4}$ solution was used as the buffer solution and the $\mathrm{pH}$ was adjusted to 5.0 by using dilute orthophosphoric acid. The

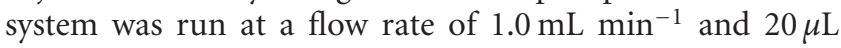
of sample was injected in the chromatographic system. The column temperature was maintained at $30^{\circ} \mathrm{C}$ and detection wavelength was set at $220 \mathrm{~nm}$ for simultaneous determination of camylofin dihydrochloride and nimesulide. A typical HPLC chromatogram for simultaneous determination of camylofin dihydrochloride and nimesulide from pharmaceutical formulation is shown in Figures 3 and 4.

2.3. Preparation of Standard Solutions. The stock solution of camylofin dihydrochloride $\left(1250 \mu \mathrm{g} \mathrm{mL}^{-1}\right)$ was prepared by dissolving $25.0 \mathrm{mg}$ of camylofin dihydrochloride (100.1\%) in 
TABLe 1: Optimization of LC method.

\begin{tabular}{|c|c|c|c|c|}
\hline Mobile Phase used & Column used & Flow rate & Observation & Result \\
\hline $\begin{array}{l}\text { DI water : acetonitrile } \\
(500: 500)\end{array}$ & $\begin{array}{l}\text { Waters symmetry } \\
\mathrm{C} 18,250 \times 4.6,5 \mu\end{array}$ & $1.0 \mathrm{~mL} \mathrm{~min}^{-1}$ & No peaks observed & Method (rejected) \\
\hline $\begin{array}{l}\text { DI water : acetonitrile } \\
(500: 500)\end{array}$ & $\begin{array}{l}\text { Varian Chromosphere } \\
5 \mathrm{C} 18,250 \times 4.6,5 \mu\end{array}$ & $1.5 \mathrm{~mL} \mathrm{~min}^{-1}$ & $\begin{array}{l}\text { Long run time and } \\
\text { improper peak shape }\end{array}$ & Method (rejected) \\
\hline $\begin{array}{l}\text { DI water: methanol } \\
(500: 500)\end{array}$ & $\begin{array}{l}\text { Varian Chromosphere } \\
5 \mathrm{C} 18,250 \times 4.6,5 \mu\end{array}$ & $1.5 \mathrm{~mL} \mathrm{~min}^{-1}$ & $\begin{array}{l}\text { Poor resolution and } \\
\text { bad peak shape }\end{array}$ & Method (rejected) \\
\hline $\begin{array}{l}\text { Buffer solution } \\
\text { pH5.0: methanol } \\
(500: 500)\end{array}$ & $\begin{array}{l}\text { Varian Chromosphere } \\
5 \mathrm{C} 18,250 \times 4.6,5 \mu\end{array}$ & $1.0 \mathrm{~mL} \mathrm{~min}^{-1}$ & $\begin{array}{l}\text { Low resolution } \\
\text { between first two } \\
\text { peaks }(<2.0)\end{array}$ & Method (rejected) \\
\hline $\begin{array}{l}\text { Buffer solution } \\
\text { pH5.0: methanol } \\
(500: 500)\end{array}$ & $\begin{array}{l}\text { Varian Chromosphere } \\
5 \mathrm{C} 18,250 \times 4.6,5 \mu\end{array}$ & $1.0 \mathrm{~mL} \mathrm{~min}^{-1}$ & $\begin{array}{l}\text { Good resolution and } \\
\text { great peak shape }\end{array}$ & Method (accepted) \\
\hline
\end{tabular}

TABLE 2: Result of system suitability.

\begin{tabular}{lccc}
\hline Parameters & Caffeine (IS) & $\begin{array}{c}\text { Camylofin } \\
\text { dihydrochloride }\end{array}$ & Nimesulide \\
\hline Resolution & NA & 4.6 & 18.5 \\
Tailing factor & 1.1 & 1.1 & 1.0 \\
Theoretical plates & 10351 & 457378 & 472684 \\
\hline
\end{tabular}

TABLE 3: Results of linearity.

\begin{tabular}{lccc}
\hline Analyte & Slope & Intercept & $\begin{array}{c}\text { Correlation coefficient }\left(R^{2}\right) \\
(n=5)\end{array}$ \\
\hline $\begin{array}{l}\text { Camylofin } \\
\text { dihydrochloride }\end{array}$ & 0.006 & 0.00003 & 0.99994 \\
Nimesulide & 0.003 & 0.0025 & 0.99998 \\
\hline
\end{tabular}

TABLE 4: Results of assay experiment.

\begin{tabular}{lcc}
\hline Results & $\begin{array}{c}\text { Camylofin } \\
\text { dihydrochloride }\end{array}$ & Nimesulide \\
\hline $\begin{array}{l}\text { Drug found in } \mathrm{mg} / \mathrm{tab} \\
\text { (mean) }\end{array}$ & 50.1 & 99.9 \\
\% mean assay & 100.2 & 99.9 \\
\% RSD & 0.31 & 0.18 \\
\hline
\end{tabular}

TABle 5: Ruggedness of assay experiment.

\begin{tabular}{lcc}
\hline Results & $\begin{array}{c}\text { Camylofin } \\
\text { dihydrochloride }\end{array}$ & Nimesulide \\
\hline $\begin{array}{l}\text { Drug found in mg/tab } \\
\text { (mean) }\end{array}$ & 50.2 & 99.6 \\
\% mean assay & 100.4 & 99.6 \\
\% RSD & 0.41 & 0.35 \\
\% difference wr.t. precision & 0.2 & 0.3 \\
\hline
\end{tabular}

methanol in a standard $20 \mathrm{~mL}$ volumetric flask (stock solution A). The stock solution of nimesulide $\left(2500 \mu \mathrm{g} \mathrm{mL}^{-1}\right)$ was prepared by dissolving $50.1 \mathrm{mg}$ of nimesulide (99.8\%) in methanol in a standard $20 \mathrm{~mL}$ volumetric flask (stock solution B). Internal standard (caffeine) stock solution $\left(2000 \mu \mathrm{g} \mathrm{mL}^{-1}\right)$ was prepared by dissolving $200.2 \mathrm{mg}$ of
TABLE 6: Results of accuracy experiment.

\begin{tabular}{lcccc}
\hline \multirow{2}{*}{ Analyte } & \multicolumn{2}{c}{ Amount added } & \% Recovery & \% RSD $(n=3)$ \\
& $\%$ & $\mu \mathrm{g} \mathrm{mL}^{-1}$ & & \\
\hline Camylofin & 50 & 125.0 & 100.3 & 0.12 \\
dihydrochloride & 100 & 250.0 & 100.2 & 0.35 \\
& 150 & 375.0 & 101.1 & 0.22 \\
\hline \multirow{3}{*}{ Nimesulide } & 50 & 250.0 & 99.8 & 0.41 \\
& 100 & 500.0 & 100.1 & 0.34 \\
& 150 & 750.0 & 100.5 & 0.50
\end{tabular}

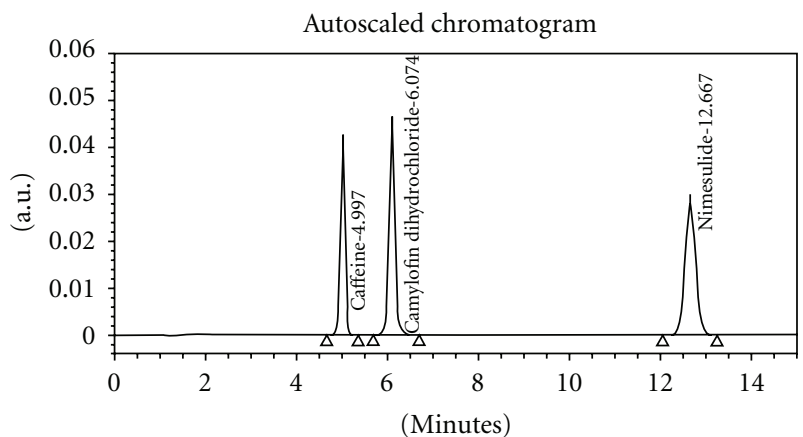

Figure 5: A typical chromatogram of sample preparation: caffeine (4.997 $\mathrm{min})$, camylofin dihydrochloride $(6.074 \mathrm{~min})$ and nimesulide (12.667 min).

caffeine in methanol in a $100 \mathrm{~mL}$ standard volumetric flask (stock solution C).

Transferred $10.0 \mathrm{~mL}$ of each stock solution A, B and C to a $50 \mathrm{~mL}$ volumetric flask and diluted up to the mark with methanol. This is working standard solution.

2.4. Preparation of Sample Solution. For analysis of the tablet dosage form, twenty tablets were weighed individually and their average weight was determined. The tablets were crushed to fine homogenous powder and quantity equivalents to ten tablets were transferred in a $200 \mathrm{~mL}$ volumetric flask. Added about $100 \mathrm{~mL}$ of methanol to the volumetric flask, shaken for 10 minutes and then sonicated 
TABLE 7: Results of robustness experiment: change of flow rate.

\begin{tabular}{lcccc}
\hline Parameters & \multicolumn{2}{c}{ Low flow $(0.8 \mathrm{~mL} / \mathrm{min})$} & \multicolumn{2}{c}{ High flow $(1.2 \mathrm{~mL} / \mathrm{min})$} \\
Camylofin & Nimesulide & Camylofin & Nimesulide \\
dihydrochloride & 4.82 & 19.10 & 4.41 & 18.21 \\
\% assay & 100.2 & 100.3 & 100.2 & 100.5 \\
\hline
\end{tabular}

TABLE 8: Results of robustness experiment: change of column temperature.

\begin{tabular}{lcccc}
\hline Parameters & \multicolumn{2}{c}{$\begin{array}{c}\text { Low column temperature }\left(28^{\circ} \mathrm{C}\right) \\
\text { Camylofin } \\
\text { dihydrochloride }\end{array}$} & Nimesulide & \multicolumn{2}{c}{$\begin{array}{c}\text { High column temperature }\left(32^{\circ} \mathrm{C}\right) \\
\text { Camylofin } \\
\text { dihydrochloride }\end{array}$} & Nimesulide \\
\hline Resolution & 4.78 & 18.72 & 4.75 & 18.71 \\
$\%$ assay & 99.8 & 100.2 & 100.1 & 100.1 \\
\hline
\end{tabular}

for 15 minutes. The solution was allowed to stand at room temperature for 20-30 minutes and filtered through Whatman no. 41 filter paper. The residue was washed with Methanol and the combined filtrate was made up to the mark with the same solvent. $5.0 \mathrm{~mL}$ of filtrate was quantitatively transferred to a $50 \mathrm{~mL}$ volumetric flask, $10.0 \mathrm{~mL}$ of internal standard solution was added to it and solution was diluted up to the mark with methanol.

\section{Results and Discussion}

3.1. HPLC Method Development and Optimization. To develop a suitable RP-LC method for the analysis of camylofin dihydrochloride, and nimesulide in their dosage form, different permutation and combinations were tried.

Several mobile phases using different organic solvents as part of mobile phase were tried (Table 1).

In the optimized conditions caffeine, camylofin dihydrochloride and nimesulide were well separated with a resolution greater than 4.6 and the typical retention times of Caffeine, camylofin dihydrochloride, and nimesulide were about $5.0 \mathrm{~min}, 6.1 \mathrm{~min}$, and $12.7 \mathrm{~min}$, respectively.

3.2. System Suitability. System suitability tests are used to verify that the reproducibility of the equipment is adequate for the analysis to be carried out. System suitability tests were performed as per the general chapter $<621>$ in USP 32 NF 27 to confirm the suitability and reproducibility of the system. The test was carried out by injecting $20-\mu \mathrm{L}$ standard solutions of camylofin dihydrochloride, nimesulide of strengths $250 \mu \mathrm{g} \mathrm{mL}^{-1}$ and $500 \mu \mathrm{g} \mathrm{mL}^{-1}$ using caffeine as an internal standard. Five replicate injections were made. The $\%$ RSD values of camylofin dihydrochloride and nimesulide were 0.31 and 0.18 , respectively. The $\%$ RSD values were found to be satisfactory and meeting the requirements of the general chapter <621> in USP 32 NF 27 (\%RSD not more than $2.0 \%$ ). Theoretical plates, resolution, and tailing factor were determined and are presented in Table 2. A typical chromatogram of diluents, placebo, standard, and sample solution is shown in Figures 2-5.
3.3. Method Validation. Method validation was performed as per ICH guidelines [20] (International Conference on Harmonization, ICH Harmonized Tripartite Guidelines Validation of analytical procedures: methodology, Fed. Regist., 1997).

3.3.1. Linearity. Linearity was evaluated by analysis of working standard solutions of camylofin dihydrochloride and nimesulide of seven different concentrations. The range of linearity was from $250-750 \mu \mathrm{g} \mathrm{mL}^{-1}$ for nimesulide and 125-375 $\mu \mathrm{g} \mathrm{mL}^{-1}$ for camylofin dihydrochloride. The peak area ratio and concentration of each drug were subjected to regression analysis to calculate the calibration equations and correlation coefficients. The linearity plot of camylofin dihydrochloride and nimesulide is shown in Figures 6 and 7. The regression data obtained for the camylofin dihydrochloride and nimesulide is represented in Table 3. The result in Table 3 shows that within the concentration range mentioned above, there was an excellent correlation between peak area ratio and concentration.

3.3.2. Sensitivity. Sensitivity was determined by establishing the limit of detection (LOD) and limit of quantification (LOQ). The limit of detection (LOD) and limit of quantitation (LOQ) were established at signal-to-noise ratio of $3: 1$ and $10: 1$, respectively. The LOD and LOQ of camylofin dihydrochloride and nimesulide were experimentally determined by six injections of each drug. The LOD of camylofin dihydrochloride and nimesulide was found to be $0.07 \mu \mathrm{g} \mathrm{mL}^{-1}$ and $0.14 \mu \mathrm{g} \mathrm{mL}^{-1}$, respectively. The LOQ of camylofin dihydrochloride and nimesulide was found to be $0.06 \mu \mathrm{g} \mathrm{mL}^{-1}$ and $0.13 \mu \mathrm{g} \mathrm{mL}^{-1}$, respectively.

3.3.3. Precision. Repeatability was studied by carrying out system precision. System precision was determined from results for six replicate injections of the mixed standard solutions. The relative standard deviation (RSD) was less than 2\%. Method precision was determined from results from six independent determinations at $100 \%$ of the test concentrations of camylofin dihydrochloride and nimesulide 
TABLE 9: Results of robustness experiment: change of mobile phase composition.

\begin{tabular}{|c|c|c|c|c|}
\hline \multirow[t]{2}{*}{ Parameters } & \multicolumn{2}{|c|}{$\begin{array}{l}\text { Low organic composition } \\
\text { (Buffer solution } \mathrm{pH} 5.0: \mathrm{MeOH}:: 630: 370 \text { ) }\end{array}$} & \multicolumn{2}{|c|}{$\begin{array}{c}\text { High organic composition } \\
\text { (Buffer solution pH } 5.0: \mathrm{MeOH}:: 570: 430)\end{array}$} \\
\hline & $\begin{array}{c}\text { Camylofin } \\
\text { dihydrochloride }\end{array}$ & Nimesulide & $\begin{array}{c}\text { Camylofin } \\
\text { dihydrochloride }\end{array}$ & Nimesulide \\
\hline Resolution & 5.11 & 19.24 & 4.30 & 17.25 \\
\hline$\%$ assay & 99.7 & 100.2 & 100.3 & 100.4 \\
\hline
\end{tabular}

TABLE 10: Results of solution stability.

\begin{tabular}{lcccc}
\hline \% Assay & Camylofin dihydrochloride & $\begin{array}{c}\text { \% difference w.r.t. } \\
\text { initial assay }\end{array}$ & Nimesulide & $\begin{array}{c}\text { \% difference w.r.t. } \\
\text { initial assay }\end{array}$ \\
\hline Initial & 100.2 & Not applicable & 100.1 & Not applicable \\
24 hours & 99.9 & 0.3 & 99.8 & 0.3 \\
48 hours & 99.6 & 0.6 & 99.6 & 0.5 \\
72 hours & 99.1 & 0.7 & 99.4 & 0.7 \\
\hline
\end{tabular}

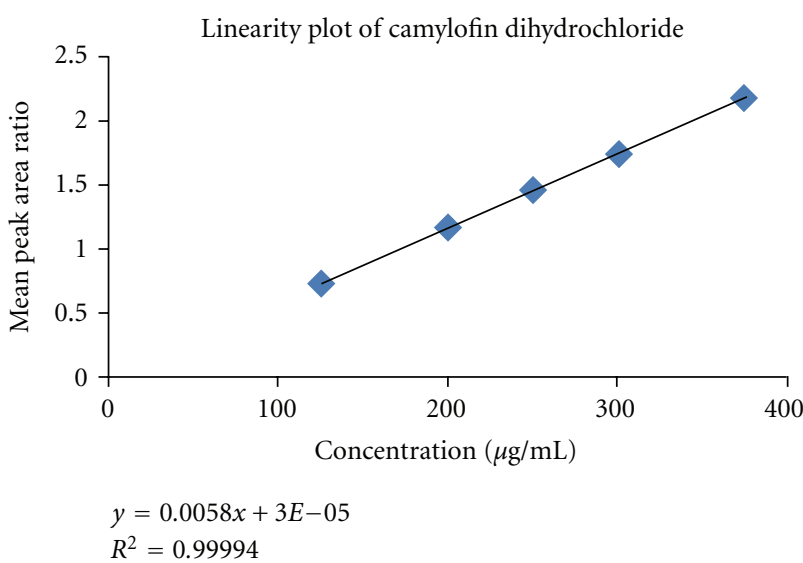

FIGURE 6: Linearity plot of camylofin dihydrochloride.

in the product. The \% RSD for camylofin dihydrochloride and nimesulide was found to be 0.67 and 0.71 , respectively. Refer to Table 4.

3.3.4. Ruggedness. Ruggedness study was done by injecting six individual sample preparations at $100 \%$ of the test concentrations of camylofin dihydrochloride and nimesulide on different day and different HPLC system. The mean $\%$ assay obtained was compared with mean \% assay of precision study. The relative standard deviation (RSD) was less than $2 \%$. The \% RSD for camylofin dihydrochloride and nimesulide was found to be 0.58 and 0.87 , respectively. Refer to Table 5.

3.3.5. Accuracy. Accuracy of the developed method was confirmed by doing recovery study as per ICH guidelines at three different concentration levels 50\%, 100\%, and $150 \%$ by replicate analysis $(n=3)$. The results of accuracy study were reported in Table 6 . The results indicate the method is

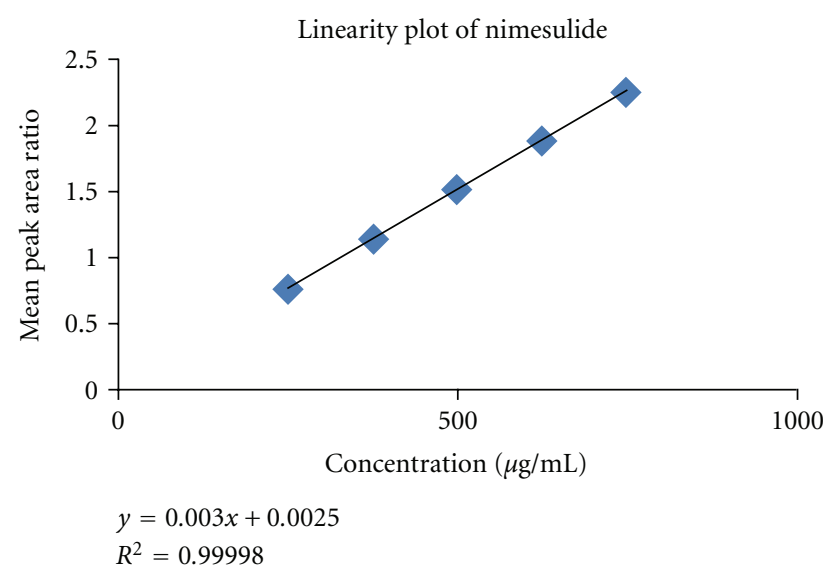

FIGURE 7: Linearity plot of nimesulide.

highly accurate for simultaneous determination of camylofin dihydrochloride and nimesulide.

3.3.6. Robustness. By deliberate change in experimental condition the resolution between caffeine, camylofin dihydrochloride, and nimesulide were evaluated. To study the effect of flow rate on system suitability parameters, 0.2 units changed, that is, 0.8 and $1.2 \mathrm{~mL} \mathrm{~min}^{-1}$. The effect of column temperature was studied at $28^{\circ} \mathrm{C}$ and $32^{\circ} \mathrm{C}$. In all the above varied conditions, the components of the mobile phase were held constant. The effect of mobile phase was studied by changing the ratio of mobile phase composition. The organic phase composition was changed by $5 \%$. The resolution between the peak between caffeine and camylofin dihydrochloride was greater than 4.3 and camylofin dihydrochloride and nimesulide was greater than 17.2. The results of resolution and \% assay are mentioned in Tables 7-9. 
TABLE 11: Forced degradation for Camylofin dihydrochloride.

\begin{tabular}{|c|c|c|c|c|c|c|}
\hline Stress condition & Time & $\begin{array}{c}\% \text { assay of } \\
\text { camylofin } 2 \mathrm{HCl}\end{array}$ & $\begin{array}{c}\text { Degradation (\%) } \\
\text { w.r.t. control }\end{array}$ & Purity angle & Purity threshold & Peak Purity \\
\hline Control sample & NA & 100.1 & NA & 0.220 & 0.250 & Passes \\
\hline Acid hydrolysis (1 M HCl) & $48 \mathrm{~h}$ & 89.2 & 10.9 & 0.220 & 0.252 & Passes \\
\hline $\begin{array}{l}\text { Base hydrolysis }(0.05 \mathrm{~N} \\
\mathrm{NaOH})\end{array}$ & $12 \mathrm{~h}$ & 78.9 & 21.2 & 0.199 & 0.240 & Passes \\
\hline Oxidation $\left(3 \% \mathrm{H}_{2} \mathrm{O}_{2}\right)$ & $48 \mathrm{~h}$ & 90.1 & 10.1 & 0.204 & 0.248 & Passes \\
\hline Thermal $\left(105^{\circ} \mathrm{C}\right)$ & 5 days & 92.5 & 7.6 & 0.218 & 0.254 & Passes \\
\hline $\begin{array}{l}\text { Light (photolytic } \\
\text { degradation) }\end{array}$ & 10 days & 94.5 & 5.6 & 0.217 & 0.251 & Passes \\
\hline
\end{tabular}

TABLE 12: Forced degradation for nimesulide.

\begin{tabular}{|c|c|c|c|c|c|c|}
\hline Stress condition & Time & $\begin{array}{c}\% \text { Assay of } \\
\text { camylofin } 2 \mathrm{HCl}\end{array}$ & $\begin{array}{c}\text { Degradation (\%) } \\
\text { w.r.t. control }\end{array}$ & Purity angle & Purity threshold & Peak purity \\
\hline Control sample & NA & 100.5 & NA & 0.184 & 0.200 & Passes \\
\hline Acid hydrolysis (1 M HCl) & $48 \mathrm{~h}$ & 96.4 & 4.1 & 0.182 & 0.200 & Passes \\
\hline $\begin{array}{l}\text { Base hydrolysis } \\
(0.05 \mathrm{~N} \mathrm{NaOH})\end{array}$ & $12 \mathrm{~h}$ & 82.5 & 18.0 & 0.189 & 0.201 & Passes \\
\hline Oxidation $\left(3 \% \mathrm{H}_{2} \mathrm{O}_{2}\right)$ & $48 \mathrm{~h}$ & 97.1 & 3.4 & 0.179 & 0.200 & Passes \\
\hline Thermal $\left(105^{\circ} \mathrm{C}\right)$ & 5 days & 94.1 & 6.4 & 0.180 & 0.205 & Passes \\
\hline $\begin{array}{l}\text { Light } \\
\text { (photolytic degradation) }\end{array}$ & 10 days & 90.1 & 10.4 & 0.187 & 0.204 & Passes \\
\hline
\end{tabular}

3.3.7. Solution Stability and Mobile Phase Stability. The solution stability of Camylofin dihydrochloride and Nimesulide was carried out by leaving the test solutions of sample in a tightly capped volumetric flask at room temperature for 72 hours. The same sample solutions were assayed for 24 hours interval up to the study period against freshly prepared standard solution.

Mobile phase stability was also carried out for 72 hours by injecting the freshly prepared sample solutions for every 24 hours interval. The \% assay of camylofin dihydrochloride and nimesulide were checked in the test solutions. Mobile phase prepared was kept constant during the study period. The \% RSD of assay of camylofin dihydrochloride and nimesulide during solution stability and mobile phase stability experiments was within 1.0. No significant changes were observed in the content of camylofin dihydrochloride and nimesulide during solution stability and mobile phase stability experiments. Sample solutions and mobile phase used during the experiment were stable upto the study period of 72 hours. The results are reported in Table 10.

3.3.8. Stress Testing (Forced Degradation). To further confirm the stability indicating nature of the analytical method, camylofin dihydrochloride and nimesulide were subjected to stress testing as per ICH-recommended test conditions. The drugs were subjected to acid hydrolysis by using $1.0 \mathrm{M}$ hydrochloric acid and base hydrolysis by using $0.05 \mathrm{~N}$ sodium hydroxide solution; oxidation by using 3.0\% v/v solution of hydrogen peroxide; thermal and photolysis.
Photo-stability studies were carried out in a photo stability chamber (Sanyo, Leicestershire, UK). Thermal-stability studies were carried out in a dry air oven (VWR, USA).

The objective of stress study was to generate the degradation products under various stress conditions. The stress conditions varied both in terms of temperature and time from moderate to extreme to achieve appropriate degradation. The spectral purity of main peaks was evaluated using photodiode array detector and empower software to verify that the degradation peaks are well resolved from the main peaks.

The peak purity of the stressed samples was checked by using a waters 2996 photo diode array detector (PDA). The purity angle was within the purity threshold limit in all of the stressed samples, demonstrating the homogeneity of the analyte peak. The results for camylofin dihydrochloride and nimesulide are reported in Tables 11 and 12, respectively.

\section{Conclusion}

The present study illustrates a validated RP-LC method for camylofin dihydrochloride and nimesulide. The analytical method is simple, specific, rugged, and stability indicating. Stress testing showed that all degradation products were well separated from camylofin dihydrochloride and Paracetamol, confirming its stability-indicating capability. The method seems to be suitable for quality control in the pharmaceutical industry because of its sensitivity, simplicity, and selectivity. 


\section{References}

[1] Sweetman and C. Sean, Martindale: The Complete Drug Reference, 36th edition, 2009.

[2] M. J. Oneil, A. Smith, and P. E. Heckelman, The Merck Index, Merck \& Co., White House Station, NJ, USA, 13th edition, 2001.

[3] G. Khaksa and N. Udupa, "Rapid and sensitive method for determination of nimesulide in human plasma by highperformance liquid chromatography," Journal of Chromatography $B$, vol. 727, no. 1-2, pp. 241-244, 1999.

[4] D. J. Jaworowicz, M. T. Filipowski, and K. M. K. Boje, "Improved high-performance liquid chromatographic assay for nimesulide," Journal of Chromatography B, vol. 723, no. 12, pp. 293-299, 1999.

[5] S. S. Zarapkar, N. P. Bhandari, and U. P. Halkar, "Simultaneous determination of nimesulide and chlorzoxazone in pharmaceutical dosage by reverse phase high performance liquid chromatography," Indian Drugs, vol. 37, no. 10, pp. 469-473, 2000.

[6] B. Raman and D. Patil, "RP-HPLC for simultaneous estimation of Tizanidine and Nimesulide in tablets," Indian Drugs, vol. 39, no. 7, pp. 392-394, 2002.

[7] P. Kovaříková, M. Mokrý, and J. Klimeš, "Photochemical stability of nimesulide," Journal of Pharmaceutical and Biomedical Analysis, vol. 31, no. 4, pp. 827-832, 2003.

[8] B. S. Nagaralli, J. Seetharamappa, B. G. Gowda, and M. B. Melwanki, "High-performance liquid chromatographic method for the determination of nimesulide in pharmaceutical preparations," Journal of Analytical Chemistry, vol. 58, no. 8, pp. 778-780, 2003.

[9] R. Nageswara Rao, S. Meena, D. Nagaraju, and A. Raghu Ram Rao, "Development and validation of a reversed-phase liquid chromatographic method for separation and simultaneous determination of COX-2 inhibitors in pharmaceuticals and its application to biological fluids," Biomedical Chromatography, vol. 19, no. 5, pp. 362-368, 2005.

[10] P. D. Tzanavaras and D. G. Themelis, "Validated highthroughput HPLC assay for nimesulide using a short monolithic column," Journal of Pharmaceutical and Biomedical Analysis, vol. 43, no. 4, pp. 1483-1487, 2007.

[11] H. Nimje, S. Wate, D. Dharkar, and R. Razdan, "Simultaneous RPHPLC determination of nimesulide and tizanidine in tablets," Indian Journal of Pharmaceutical Sciences, vol. 69, no. 2, pp. 281-283, 2007.

[12] M. Mokrý, J. Klimeš, and J. Pechová, "HPLC analysis of a syrup containing nimesulide and its hydrolytic degradation product," Chemical Papers, vol. 64, no. 3, pp. 405-408, 2010.

[13] V. B. Patravale, S. D'Souza, and Y. Narkar, "HPTLC determination of nimesulide from pharmaceutical dosage forms," Journal of Pharmaceutical and Biomedical Analysis, vol. 25, no. 3-4, pp. 685-688, 2001.

[14] P. S. Barde, A. Y. Desai, M. N. Shikha et al., "Simultaneous HPLTC determination of Camylofin dihydrochloride in pharmaceutical preparations," TSI Journal, vol. 10, no. 3, 2011.

[15] F. A. Elbarbry, M. M. Mabrouk, and M. A. El-Dawy, "Determination of the analgesic components of Spasmomigraine tablet by liquid chromatography with ultraviolet detection," Journal of the Association of Official Agricultural Chemists, vol. 90, no. 1, pp. 94-101, 2007.

[16] N. N. Kadam, P. C. Patil, and R. R. Singh, "A stabilityindicating RP-HPLC determination of Camylofin Dihydrochloride in drug substance," International Journal of Pharmacy and Pharmaceutical Sciences, vol. 3, no. 3, pp. 153-158, 2011.
[17] P. S. Barde, A. Y. Desai, S. M. N. Roy, and V. V. Vaidya, "Simultaneous RP HPLC determination of Camylofin dihydrochloride in Pharmaceutical preparation," TSI Journal, vol. 7, no. 10, 2008.

[18] R. R. Singh, M. V. Rathnam, and R. Vegesna, "Simultaneous RP HPLC determination of Camylofin dihydrochloride and Paracetamol in Pharmaceutical preparations," TSI Journal, vol. 7, no. 11, 2008.

[19] M. V. Rathnam and R. R. Singh, "Simultaneous RP HPLC determination of Camylofin dihydrochloride and Diclofenac Potassium in Pharmaceutical preparations," Pharmaceutica Analytica Acta, vol. 1, article 108, 2010.

[20] L. R. Snyder, J. J. Kirland, and J. L. Glajch, Practical HPLC Method Development, John Wiley and Sons, New York, NY, USA, 2nd edition, 1997. 


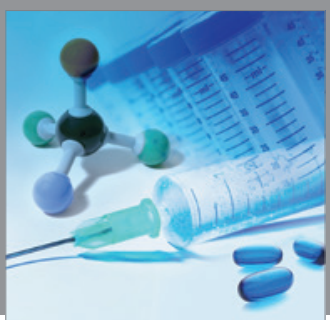

International Journal of

Medicinal Chemistry

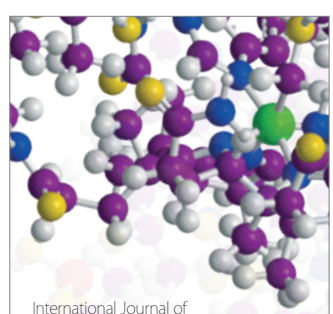

Carbohydrate Chemistry

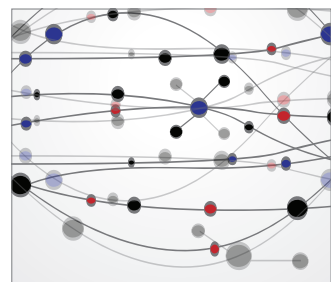

The Scientific World Journal
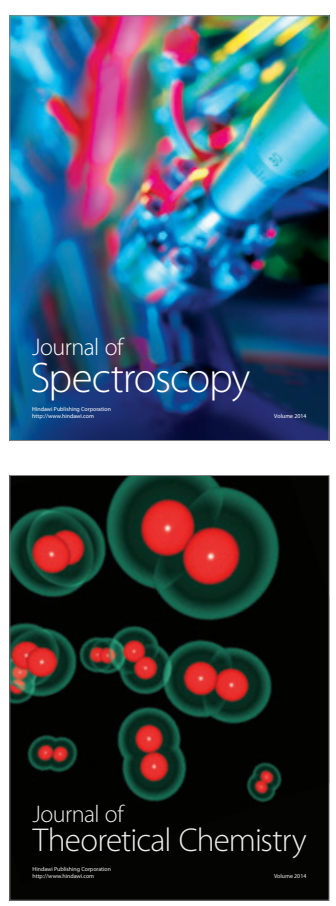
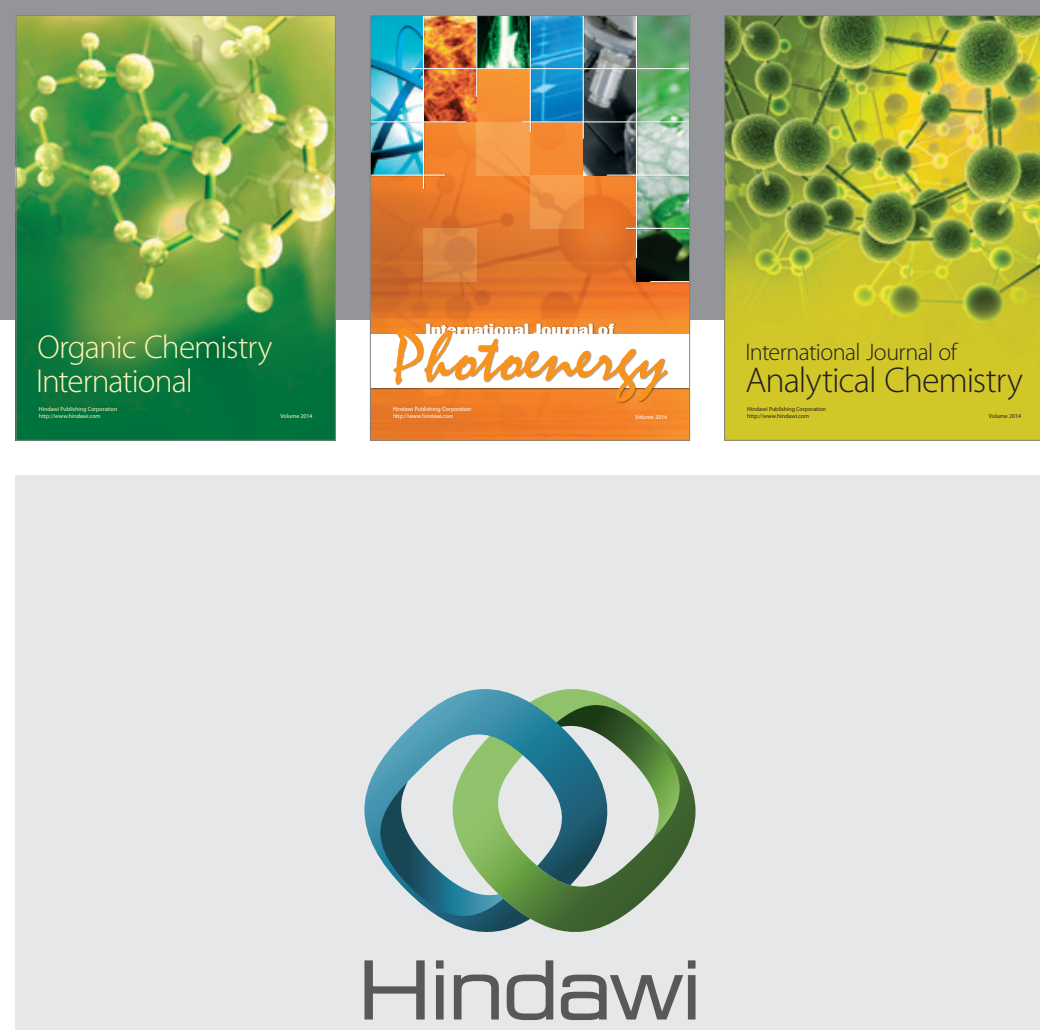

Submit your manuscripts at

http://www.hindawi.com
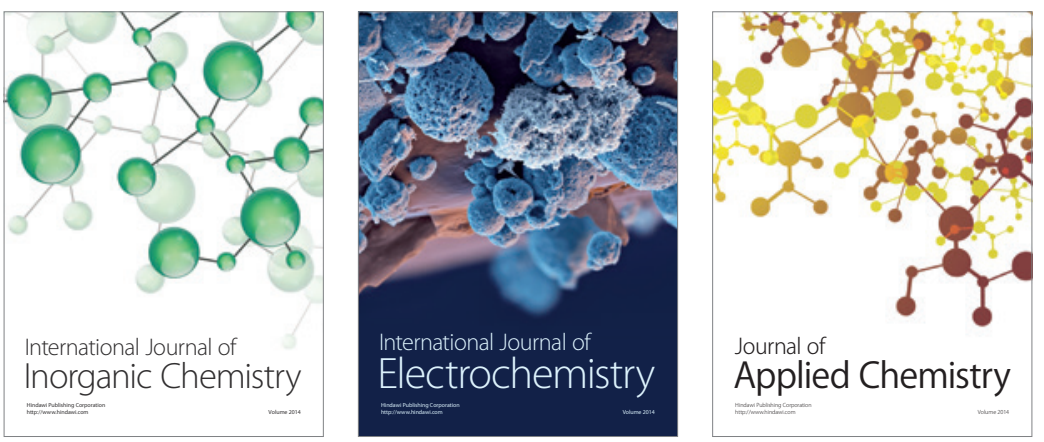

Journal of

Applied Chemistry
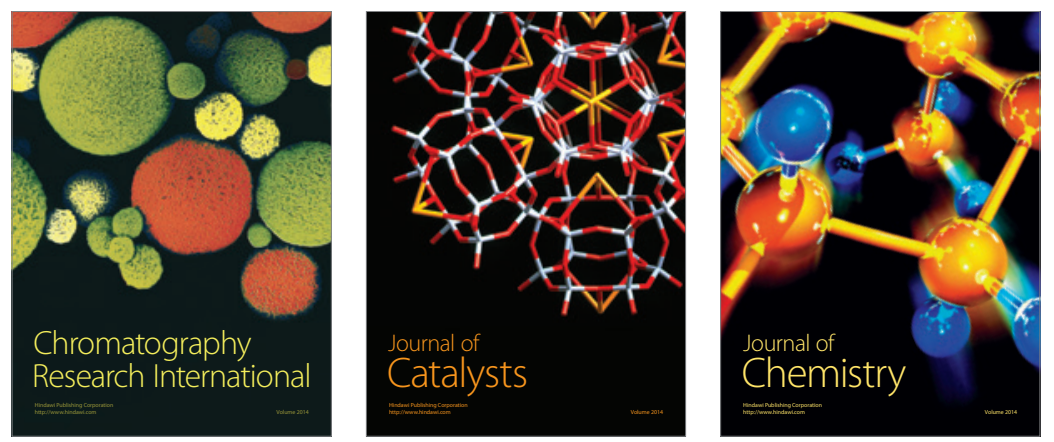
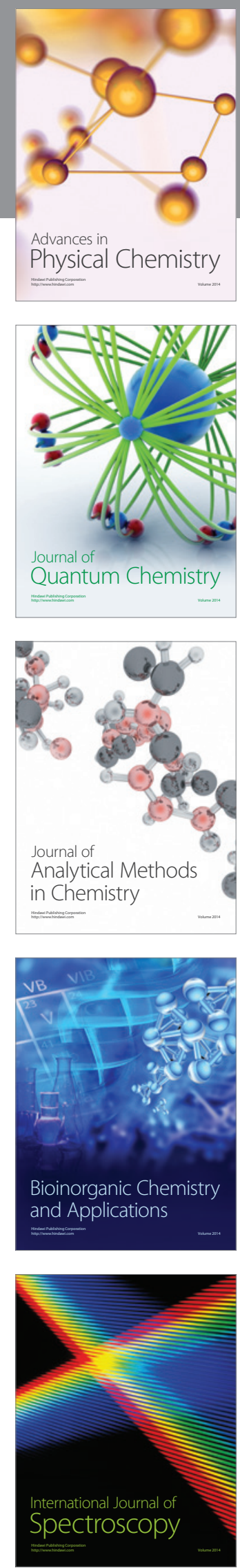